\title{
Determination of the Demographic Variables Predicting Accommodation Business Employees' Organizational Commitment and Job Satisfaction through CHAID Analysis
}

\author{
Engin ÜNGÜREN \\ Akdeniz University \\ Alanya Faculty of Business, \\ Department of Business Administration \\ 07425 Kestel Alanya - Antalya, Turkey \\ enginunguren@gmail.com
}

\author{
Rüya EHTIYAR \\ Akdeniz Üniversitesi \\ Faculty of Tourism, \\ Department of Tourism Management \\ 07058 Kampus - Antalya, Turkey \\ ehtiyar@akdeniz.edu.tr
}

\begin{abstract}
The main objective of this research is to determine the demographic variables that affect job satisfaction and organizational commitment attitudes via CHAID analysis which is one of the decision tree techniques. CHAID analysis creates sub-clusters by grouping the factors that affect the dependant variable in line with their importance levels and allows the results to be understood and interpreted more easily by displaying the relationship between variables visually. The research was carried out with 821 employees working in five star accommodation businesses in Alanya, Turkey. Survey forms were used as data collection tool. The collected data were analyzed by descriptive statistics, cluster analysis and CHAID analysis. The results of the research point a strong positive relationship between organizational commitment and job satisfaction. According to the CHAID analysis results, age was the dominant demographic variable influential on job satisfaction and organizational commitment attitudes. It was also found that job satisfaction and organizational commitment scores of the employees differ significantly in terms of department, marital status, education, status and gender. As a result of CHAID analysis it was determined that "the housekeeping, bar and kitchen department employees in the age range of 18 to 27 " and "the married male employees in the age range of 28 to 37 " predominantly have negative job satisfaction and organizational commitment attitude. Another result of CHAID analysis has also revealed that "high school and college graduate employees in the age range of 38 to 47 " and "48 and over" totally have positive attitude in terms of job satisfaction and organizational commitment.
\end{abstract}

Keywords: Demographic Variables, Job Satisfaction, Organization Commitment, Accommodation Business, CHAID Analysis, Alanya 


\section{Introduction}

Job satisfaction and organizational commitment are two of the most prevalent work attitudes examined in the business and organizational literature (Mohammed and Eleswed, 2013: 43). Job satisfaction and organizational commitment are among the most commonly researched topics in organizational behavior and management literature because of being considered as the most important criteria in determining the organizational health (Suma and Lesha, 2013: 42). The researchers indicate that job satisfaction is an important issue due to particular reasons as increasing productivity and performance (Sarwar and Ogre, 2013; Sousa-Poza and Sousa-Poza, 2000; Çekmecelioğlu, 2006), providing consumer satisfaction and loyalty (Fosam et al., 1998; Bansal et al., 2001) reducing absenteeism and the staff turnover rate (Harrison et al., 2006; Chen, 2008; Shields and Price, 2002; George, 1992; Organ and Ryan, 1995; Judge and Locke, 1993; Tett and Meyer, 1993), predicting the organizational citizenship behavior in a positive way (Kose et al., 2003), the happiness of the employees for what they are doing (Judge and Watanabe, 1993).

In this regard, researchers and theorists have identified that organizational commitment allows employees to believe strongly in the objectives and values of the organization, to strongly desire maintaining their organizational memberships (Mathieu and Zajac, 1990; Allen and Meyer 1996; Testa, 2001), affecting work performance in a positive way (Jamal, 2011), showing an adverse relationship with intention to leave the job or absenteeism (Mowday et al., 1982; Cohen, 1993; Vandenberghe and Tremblay 2008; Alen and Meyer, 1990; Meyer and Allen, 1991), showing positive impact on efficiency, productivity and creativity (Lashley and Lee-Ross, 2003) and predicting the organizational citizenship positively (Mammen et al., 2011; Meyer and Allen, 1997). Therefore, the concepts of job satisfaction and organizational commitment have become one of primary focus of the researches carried out in the area of management and organization (Westover and Taylor 2010; Börü and Güneşer, 2005: 139).

In the researches on the relationship between job satisfaction and organizational commitment, a statistically significant relationship was determined (Cooper-Hakim and Viswesvaran, 2005; Meyer et al., 2002; Silva, 2006; Mathieu and Zajac, 1990; Dirani and Kuchinke; 2011; Salami, 2008; Ahmad and Oranya 2010; Luqman et al. 2012; Testa, 2001; Yousef, 2002; Meyer et al., 2002; Feinstein and Vondrasek, 2001; Ghazzawi \& Smith, 2009; Gaertner, 1999; Matzler and Renzl 2007; Rue and Byars, 2005; Freund, 2005). Thus, the positive interaction between job satisfaction and organizational commitment is proven via various scientific researches. Accordingly, both job satisfaction and organizational commitment affect each other in a supportive manner. The researchers who study on these topics state that in case of an increase in organizational commitment, job satisfaction would increase and in the event that the job satisfaction of the employees in the organization increases, organizational commitment would increase, as well. However, in most of the researches conducted so far, job satisfaction has been regarded as the premise of organizational commitment (Dilek, 2005: 54).

In brief, the concepts of job satisfaction and organizational commitment are considered as quite important factors in terms of effectiveness and success of the organization (Silva 2006; Namasivayam and Zhao, 2007). Hence, it was tried in the 
researches to identify and classify some of the various factors that affect job satisfaction and organizational commitment (Yüceler, 2009:449; Bayram, 2005:134).

When the researches are analyzed, it is seen that the factors affecting the job satisfaction and organizational commitment are generally classified as personal (age, sex, education level, focus of control, inner motivation, etc.), organizational (organizational justice, participation in decision-making, job security, work hours, organizational climate, etc.) and external factors (the unemployment rate, sector conditions, new business opportunities, etc.). It has also been stated that each factor affects the job satisfaction and organizational commitment levels of employees in different ways (Iverson and Buttgieg, 2004; Steers 1977; John and Taylor, 1999; Meyer et al, 1998; Yousef, 1998; DeLoria, 2001).

One of the major statistical issues in the scientific studies is to put forward not only the factors affecting the concerned phenomenon significantly but also at which levels the effect of these factors is high. CHAID analysis, one of the decision tree techniques which examine the factors affecting the changes in the dependent variables significantly, tries to equally identify the interaction of the variables in the model and in general, the combinations at the mutual level (Kayri and Boysan, 2007:139). Also, CHAID analysis is widely used to determine what kind of members a class is composed of. The purpose of this study is to determine job satisfaction and organizational commitment levels of the employees who are employed in the accommodation businesses and to create the subclasses by determining the demographic variables which affect these levels in order of priorities. Many researches were carried out on job satisfaction and organizational commitment of employees in the accommodation businesses. But any research examining with a comprehensive model which demographic variables of job satisfaction and organizational commitment have relatively more influence could not be found. Hence, applying CHAID on the impact of demographic variables of job satisfaction and organizational commitment, the relationship between the predicted and predictor variables are provided in detail in this research in a way to cover all possible hierarchy.

\section{Theoretical Framework}

Over 12,000 job satisfaction studies were published by the early 1990 s and the concept has been increasingly sophisticated and challenged. The concept of job satisfaction is very abstract and complex, even opined to be indescribable and mythical (Oyewobi et al., 2012: 179). Job satisfaction is described as employees' content and the discontent feelings as to their jobs (Davis, 1988: 95). The job satisfaction term, generally described as the employees' emotional reactions to their job, was first suggested in 1920s and its importance was understood in 1930-1940s (Agho et al.,1993: 1007). On the one hand, one of the reasons underlying the importance of job satisfaction is that it is related to life satisfaction which also affects the physical and mental health of the individual; on the other hand, another one is that it is related to the productivity (Sevimli and İşcan, 2005: 55; Smith, 2007).

Job satisfaction, which is one of the most important requirements of individuals' success, happiness and productiveness, is the feeling of content which occurs through perceiving what the job provides to the individual (Weiss 2002:174). These emotions depend on their previous business life, expectations and options they have. Job satisfaction is a sign of employees' physiologically, mentally and emotionally wellness 
(Oshagbemi, 2000: 88).

Researches on job satisfaction show that many factors such as the nature of the job, salary, rewards, promotion possibility, job security, working condition, colleagues, auditing, management style, social rights, communication, personality of the employee, demographic features, the structure of the hotel affect job satisfaction (Currivan, 1999; Friday and Friday, 2003; Lam 1995; Crossman and Abou-Zaki, 2003; Scott et al. 2006; Pelit and Öztürk, 2010). One of the most important evidences indicating whether working conditions in a work place worsen or not is job satisfaction. This is why managers should show deeper interest to the evaluation of the job satisfaction. Another reason to be interested in job satisfaction derives from its relation with the basic organizational outputs such as organizational commitment, leaving the job and performance. As long as individuals get the job they desire and that is related to their knowledge background and abilities, they can be more productive at work and can satisfy their moral and material needs (Tütüncü, 2000:108). Today, extreme uncertainty affecting many industrial organizations included within the service industry makes it obligatory to understand how to make employees productive and loyal to the organization, and this matter forms a basis for the research of job satisfaction and related factors (Cevrioğlu, 2007: 65).

As a term and way of comprehension, commitment occurs in everywhere that social emotion occurs and it is an emotional explanation of social instincts (Güneş, et al., 2009: 485). Examining organizational commitment within the organizational framework, it is seen that many different descriptions are made (Balay, 2000: 3). Considering these descriptions, organizational commitment is described as individual's strong identity union with the organization that he works for, the level of his feeling as a part of the organization, his psychological condition which allows him maintaining to be the member of the organization, the unity and harmony between his goals and those of the organization (Kök, 2006: 297; Tutar, 2007:104). From the most general perspective, organizational commitment is explained as internalization of organizational objectives and values by the organization members, their effort to be an important member of the organization, evaluating the organization as a family and considering himself as a member of this family (Allen and Meyer, 1996; Özdevecioğlu, 2003:114; Yalçın and İplik, 2005:396).

Sense of belonging which is at the core of the organizational commitment term, creates a link between individual and organization, and the employees in the organization come together under a common value, objective and culture. Due to all aforementioned reasons, organizational commitment has become a term which attracts the attention of researchers as it affects such outputs as increase in organizational production, describing yourself with the organization, level of accepting the organizational change, productivity, performance and transfer of labor force (Meyer and Herscovitch, 2001; Sığrl, 2007: 262; Şengül, 2008: 50).

Examining the descriptions on organizational commitment, it can be seen that they are classified as attitudinal (emotional) and behavioral. The basic reason underlying this difference is the division of opinion on the structure of the relationship between employee and organization and how it develops. This is why the description of commitment differs according to organizational attitude and social psychology researchers. Researchers studying on organizational attitude approach the commitment 
term from attitudinal aspect whereas those studying on social psychology examine it from the behavioral aspect.

Attitudinal approach studies focus on the conditions which reveal the commitment and the attitudinal results of the commitment (Bayram, 2005:129; Doğan and K1liç, 2007:39; Şengül, 2008: 52). Within this frame the researchers studying on organizational attitude describe the commitment term as a process of the employees' identifying themselves with the organizational aims and values and their wish to continue their membership. Attitudinal commitment emerges as a result of individual's evaluation as to working conditions and an emotional reaction that ties him to the organization, in other words the unity of individual with the organization and relative power of joining to the organization. Attitudinal commitment that focuses on employees' relation to their organizations is regarded as an orientation which leads positive attitudes such as identifying yourself with the organization, joining to the organization and commitment feeling and all these factors ends with high working performance, low absence and persistence in the job. Besides, attitudinal commitment was tried to be examined under emotional commitment category in the literature (Kök, 2006: 298). Researchers such as Allen, Meyer, March and Simon, Mowday, Steers and Porter, Boulian brought attitudinal aspect of organizational commitment to the fore (Yavuz, 2009: 55).

On the other hand, social psychologists suggested the behavioral commitment term. On the attitudinal commitment term, they focus on its effect on attitudinal change as much as its repetition tendency (Bayram, 2005:129; Doğan and Kılıç, 2007:39; Şengül, 2008: 52). Bearing the socio-psychological perspective basis, this term is related to the individuals' past experiences and their commitment to the organization in line with their harmonization with it (Kök, 2006: 298). Researchers such as Becker, Staw, Salancik described organizational commitment from attitudinal aspect. According to the behaviorists organizational commitment is proven only by its clear demonstration. Employees increase their responsibilities by maintaining their work and increased number of responsibilities makes difficult to leave from the organization (Yavuz, 2009:55).

Organizational commitment term is one of the most studied topics within organizational attitude context. There exist two main reasons underlying this interest. First of all, components of organizational commitment that tie an employee to the organization have not yet been understood. Although there are particular important findings indicating that it occurs automatically, originates from obligation or habits/indigenized values, there are other researches suggesting that it originates from cultural, organizational and demographic structure. This is why revealing the organizational commitment factors in different context and time lines are still considered as an important academic research field. Secondly, organizational commitment, within the framework of individual analysis, is a critical term in terms of the attitudes towards the organization. Researchers having studied on this topic revealed that organizational commitment is related to some quite critical organizational manners and attitudes such as quitting intention and attitude, job satisfaction and dissatisfaction and justice sense (Biçer et al., 2009: 189). 


\section{Chaid Analysis}

Besides the factors affecting the phenomenon in question significantly, one of the major statistical issues in scientific studies is to indicate to what extent the effect of these factors is high. CHAID (Chi-Squared Automatic Interaction Detector) analysis, one of the decision tree techniques which examine the factors affecting the changes in the dependent variables in a significant way, tries to equally identify the interaction among variables in the model and in general, the combinations in the mutual level (Kayri and Boysan, 2007:139). Also, CHAID analysis is widely used in order to determine what kind of members a class is composed of. It is a descriptive data analysis used for finding the relationship among many independent variables that may be in interaction with a dependent variable.

One of the most important differences between CHAID analysis and other decision tree techniques is tree derivation. Other techniques create binary trees whereas CHAID analysis creates multiple trees (Türe et al., 2009:2020). A regression equation obtained by CHAID analysis is exempt from all known classical hypotheses (normality, linearity, homogeneity etc.) because a complete population can be divided into stable sub-nodes with a strong iteration algorithm. Along this process, normality and homogeneity in the distribution of data can be obtained. With CHAID analysis, continuous and categorical data can be included in the model simultaneously (Kayri and Boysan, 2007:139; Koyuncugil, 2007: 12; Doğan, 2003: 65). In other words, scale types of dependent and independent variables can be measured with nominal, ordinal or interval scale, and there is no need to measure all the independent variables in the same size type (Saraçlı et al. 2006:181; Koyuncugil and Özgülbaş, 2008:6). Therefore, CHAID analysis does not make a parametric and non-parametric distinction and it is statistically semi-parametric in the method algorithm (Kayri and Boysan, 2007:139).

CHAID analysis is used to determine the relationships between a predicted variable and multiple predictor variables. In CHAID analysis, all predictor variables are compared and the variable that describes the predicted variable in the best way is selected and the data set is divided into sub-groups according to the selected predictor variable. These subgroups also continue to create new sub-groups for all meaningful predictor variables (Avşar and Yalçın 2015: 4).

CHAID analysis uses chi-square $\left(\mathrm{X}^{2}\right)$ statistics especially because of dealing with the relationship and interaction of independent variables with each other. Chi-square test statistics is about the dependency between variables (Kayri and Boysan, 2007:140; Erbaş and Güneş, 1998: 381; Koyuncugil, 2007: 12; İmamoğlu, 2005: 50; SPSS, 2001). Along with determining the relationship among independent variables and the dependent variables, CHAID analysis also reveals the interaction of independent variables with each other (Kayri and Boysan, 2008:169).

\section{Research Methodology \\ Purpose of the Study}

In the deep rivalry environment, the key factor for an accommodation business to make a difference is the employees. Accommodation businesses are type of businesses that produce service and mostly these productions take place in an environment where customers are also found and served, the employee and customer relations are quite intense and moral level of the employee is extremely influential in customer satisfaction (Avc1 and Küçükusta, 2009: 33). In a sector where the customer purchasing the service 
and the employee providing it are in a face to face relationship, it is impossible for an employee with low job satisfaction and organizational commitment to satisfy the customer in a perfect manner (Toker, 2007: 92). This situation reveals the importance of specifying the factors affecting employees' job satisfaction and organizational commitment. Although there are many researches carried out on job satisfaction and organizational commitment of employees in accommodation businesses, it is seen that researches showing in detail the effects of demographic differences on job satisfaction and organizational commitment, their significance level and covering all possible hierarchy are not so common. In this frame the main purpose of this research is to specify demographic features of employees in the accommodation businesses and to reveal via CHAID analysis how these factors affect job satisfaction and organizational commitment. The research is carried out via CHAID analysis and the relations between all predicted and predictor variables, covering all possible hierarchies are presented in detail (Üngüren and Doğan, 2010: 50). It is considered that revealing the effect of employees' demographic features on job satisfaction and organizational commitment would make significant contribution to the literature

\section{Sample and Data Collection}

The population of the research consists of employees working in five-star accommodation and resort businesses operating in Alanya region. The reason why fivestar accommodation businesses are preferred is that they have more departments and specialized staff, large customer and employee capacity and also operate full year or approximately full-year compared to other facilities. At first, a preliminary meeting with the managers of the businesses in the region was held. In the preliminary meeting, information about the aim, scope and methods of the research was provided and managers were asked for their opinions. 17 out of 36 interviewed businesses found the research favorable and stated that the research could be carried out in their organizations. Five businesses announced that they would decide after a management consultation among themselves. On the other hand, other businesses indicated that they did not want to participate in the research. In total, 17 five-star accommodation businesses pointed out that the research could be conducted in their organizations. During the implementation process of the research, two businesses were not included in the study because of the busy season. The study was carried out with a total number of 821 employees working in15 five-star accommodation businesses in Alanya.

\section{Data Collection Tool}

In the research, survey form was utilized as data collection tool. Scales used in the survey forms are as follows.

\section{Organizational Commitment Scale}

As a result of the literature scanning it is seen that various scales were developed for determining the importance of organizational commitment, its extent and effect level from the point of organizations. In this study "Organizational Commitment Scale" developed by Meyer and Allen $(1984,1997)$ is used due to its more comprehensive scope (Organizational Commitment Questionnaire: OCQ) (Boylu et al., 2007: 61).

Many construct validity studies carried out on organizational commitment scale that Meyer and Allen developed reveal that it is a reliable and valid scale structure. In a study by Wasti (2000) conducted in order to find out organizational commitment's connotation in Turkish culture and the similarities and differences between the models 
developed in the western literature, it was observed that three dimensional organizational commitment model developed by Meyer and Allen generally might be suitable for Turkish culture and context (Wasti, 2000:404). Organizational commitment scale was designed according to 5-point likert scale ranging from "strongly disagree" (1) to "strongly agree" (5).

\section{Job Satisfaction Scale}

Job satisfaction scale developed by Batıün and Şahin (2006) was used in order to evaluate the department workers' satisfaction about their job. The employees were asked to what extent they are satisfied (content) with their job and requested to evaluate their satisfaction levels via the five-point Likert-type scale ranging from "strongly disagree"(1) to "strongly agree" (5) which was used for all items. So as to obtain evidences for the validity of the scale, two sample groups were worked with. Cronbach's alpha reliability coefficient for the whole scale calculated by Batıgün and Şahin (2006) was specified as .94 for the first sample and .96 for the second sample. Moreover reliability coefficient divided into two by using odd and even number articles were confirmed as $\mathrm{r}=.94(\mathrm{p}<.001)$ (first sample) and $\mathrm{r}=.90(\mathrm{p}<.001)$ (second sample). As a result of the article - total correlation performed in order to collect more evidences it was observed correlation coefficient differed between $r=.28(p<.001)$ and $r=.79(p<$ $.001)$ in the first sample and $r=.20(p<.05)$ and $r=.67(p<.001)$ in the second sample.

\section{Results}

A total number of 821 department employees from 15 businesses were interviewed. Examining the surveyed businesses in accordance with the departments, it is seen at most 12 and at least 4 different departments participated in the survey. In the overall total, the highest participation rate $(20 \%)$ was obtained from the restaurant department. Housekeeping with the rate of $14 \%$, bar with the rate of $13 \%$, front-office with the date of $12,5 \%$, kitchen department with the date of $9,7 \%$ follow the restaurant department. Generally, considering that food and beverage departments (restaurant-barkitchen) include the highest number of employees, it can be said that the similar distribution is observed in the survey. Following these departments, the rate for animations is $6.6 \%, 6.1 \%$ for accounting, $5.8 \%$ for technical services, $4.9 \%$ for security, $3.3 \%$ for human resources, $2.9 \%$ for public relations, $1.1 \%$ for sales and marketing department.

Table 1. The Respondent Profile

\begin{tabular}{|c|c|c|c|c|c|}
\hline Gender & $\mathbf{n}$ & $\%$ & Marital Status & $\mathbf{n}$ & $\%$ \\
\hline Female & 363 & 44,2 & Single & 396 & $\% 48,2$ \\
\hline Male & 458 & 55,8 & Married & 425 & $\% 51,8$ \\
\hline Education & $\mathbf{n}$ & $\%$ & Tourism Education & $\mathbf{n}$ & $\%$ \\
\hline Elementary school & 220 & 26,8 & Yes & 211 & $\% 25,7$ \\
\hline Senior high school & 435 & 53,0 & No & 610 & $\% 74,3$ \\
\hline University & 166 & 20,2 & & & \\
\hline Age & $\mathbf{n}$ & $\%$ & Professional Experience & $\mathbf{n}$ & $\%$ \\
\hline $18-27$ age & 209 & 25,5 & Less than 1 year & 134 & $\% 16,3$ \\
\hline $28-37$ age & 303 & 36,9 & $1-4$ years & 334 & $\% 40,7$ \\
\hline $38-47$ age & 229 & 27,9 & $5-8$ years & 180 & $\% 21,9$ \\
\hline 48 age and over & 80 & 9,7 & 9 years and over & 173 & $\% 21,1$ \\
\hline Tenure in the department & $\mathbf{n}$ & $\%$ & Tenure in the organization & $\mathbf{n}$ & $\%$ \\
\hline Less than 1 year & 134 & $\% 16,3$ & Less than 1 year & 296 & $\% 36,1$ \\
\hline $1-4$ years & 337 & $\% 41,0$ & $1-4$ years & 323 & $\% 39,3$ \\
\hline $5-8$ years & 207 & $\% 25,2$ & $5-8$ years & 169 & $\% 20,6$ \\
\hline 9 years and over & 143 & $\% 17,4$ & 9 years and over & 33 & $\% 4,0$ \\
\hline
\end{tabular}


$44 \%$ of survey participants (363 people) are female employees and 56\% (458 people) are male employees. When we analyze department employees according to marital status, almost an equal distribution is observed (48\% single, 52\% married). 53\% of survey participants (435 people) are high school graduates and they form the highest rate, 27\% (220 people) are primary school graduates and 20\% (166 people) are university graduates who form the lowest rate. The majority of the participants are young and middle aged people. In this context, it is possible to say that the participants are in a young and dynamic structure. Analyzing the participants according to their professional experience, employees experienced for 1-4 years are in the first place with the rate of $41 \%$, those with 5-8 year-experience are at in the second place with $22 \%$, those with 9 year and over experience are in the third place with $21 \%$, and those working for less than a year with $16 \%$ are in the last place. When the working hours of the employees in the department are examined, it is seen that the findings would be similar to the length of professional experience. When the age range of employees is considered at the same time, it is possible to say that each of these obtained results supports each other. Unlike the obtained results, it is seen that the participants have not been working there for so long. In other words, the length of employees' professional experience is different from the working hours in that business. It seems that the rate of the employees working in the same business for 9 years and over is only $4 \%$. According to the results, it can be said that employees in the sector change their companies frequently. According to the findings obtained from studies carried out on accommodation businesses, it is understood that staff turnover rate is high due to working conditions in the sector. Lastly, investigating the content of the education they had, it is seen that only $26 \%$ of employees took tourism education whereas $74 \%$ did not take any education on tourism. From the researches carried out in order to determine the attitudes of students towards tourism sector who have received and been receiving tourism education (King et al. 2003; Altman and Brothers, 1995; Ünlüönen, 2004; Kuşluvan and Kuşluvan 2000; Aksu and Köksal, 2005; Pelit and Güçer, 2006; Baron and Maxwell, 1993; Johnstone, 1994; Üngüren and Ehtiyar, 2009), it is understood that people having tourism education, especially university graduates wish leaving the sector and working in other sectors.

\section{Results of Factor Analyses}

At first, for ensuring the reliability of the scales used in the search, consistency indexes (Cronbach's Alpha) were specified and exploratory factor analysis was performed for the validity of the scales. The suitability of the factor analysis was decided considering the results of KMO (Kaiser-Meyer-Olkin) and Bartlett Test of Sphericity. For the structural validity of the scales factor structures were examined by applying main components method and Varimax rotation, and Cronbach alpha value of each factor was calculated. Eigen values were benefited for the calculation of the factors. 
Table 2. Organizational Commitment Factor Analysis Results

\begin{tabular}{|c|c|c|c|c|}
\hline Construct and items & $\begin{array}{c}\text { Factor } \\
\text { Loadings }\end{array}$ & Eigen values & The Ratio of Variance (\%) & Cronbach's alpha \\
\hline \multicolumn{5}{|l|}{ Factor 1: Affective Commitment } \\
\hline -AC1 & 0,86 & & & \\
\hline •AC2 & 0,81 & & & \\
\hline •AC3 & 0,75 & 9,26 & $\% 35,27$ &, 867 \\
\hline -AC4 & 0,69 & & & \\
\hline -AC5 & 0,61 & & & \\
\hline •AC6 & 0,55 & & & \\
\hline \multicolumn{5}{|l|}{ Factor2: Continuance } \\
\hline \multicolumn{5}{|l|}{ Commitment } \\
\hline$\cdot \mathrm{CC} 1$ & 0,79 & 5,81 & $\% 22,15$ & ,724 \\
\hline • $\mathrm{CC} 2$ & 0,71 & & & \\
\hline - $\mathrm{CC} 3$ & 0,67 & & & \\
\hline - $\mathrm{CC} 4$ & 0,59 & & & \\
\hline$\cdot \mathrm{CC} 5$ & 0,54 & & & \\
\hline \multicolumn{5}{|l|}{ Factor 3: Normative } \\
\hline \multicolumn{5}{|l|}{ Commitment } \\
\hline •NB1 & 0,78 & 2,06 & $\% 7,85$ & ,825 \\
\hline •NB2 & 0,66 & & & \\
\hline • NB3 & 0,65 & & & \\
\hline • NB4 & 0,53 & & & \\
\hline Kaiser-Meyer-Olkin Value & & & & ,875 \\
\hline Bartlett's test of sphericity & & & & 252,$972 ; \mathrm{sig}=0,00$ \\
\hline The Ratio of Total Variance & & & & $\% 65,27$ \\
\hline Overall Cronbach's Alpha & & & &, 843 \\
\hline
\end{tabular}

As a result of the reliability test applied to the organizational commitment scale consisting of 18 items, 3 items (items 8, 13 and 18) lowering the reliability were excluded from the research. After the removal of three items, internal consistency/reliability was found $\alpha=0.843$. This value indicates that the scale is reliable (Nunnally, 1978). After removing the propositions lowering the reliability of the scale 3 factors (dimensions) about organizational commitment were determined. The KMO (Kaiser-Meyer- Olkin Measure of Sampling Adequacy) value of the scale was found out 0,875 . Thus, it can be pointed out that the results results of factor analysis conducted on data group are quite satisfactory (Hair eta al. 1995). The Bartlett's Test of Sphericity indicates that significant factors or variables can be removed from the data. The obtained value of Bartlett's test of Sphericity (252.972; sig $=, 000$ ) were found statistically significant. Findings obtained as a result of these two tests show that sample size is sufficient and data is suitable for conducting a factor analysis. Total variance rate explained by three factors is $\% 65,27$. All factor loadings are over 0,40 .

Reliability coefficient of the first factor (affective commitment) was found (Alpha) $\alpha=0.867$. Affective commitment explained $35,27 \%$ of the total variance. Affective commitment consists of employees' affective commitment to the organization and identification and consolidation with the organization (Allen and Meyer 1990:2). It can be indicated that emotional commitment consists of employees' accepting the objectives and the values of the organization and making an extraordinary effort for the favor of the organization. An employee with emotional commitment feels a great happiness to be in the organization and does not think of leaving the job as he feels himself belongs to the organization. This is why it is a commitment type that is mostly desired to be realized and imposed to the employees (Meyer and Allen, 1997:11; Wasti 2002: 526; Akbolat, et al., 2010:44; Yüceler, 2009:448). Emotional commitment is a type of commitment that emerges with the respect and affection to the organizational objectives, sharing organizational vision and mission (Tutar, 2007: 106). Employees staying in the organization with strong emotional commitment continue staying in the 
organization not because they need but also they would like to (Doğan and Kilınç, 2007: 44). In this case the employee accepts the values of the organization strongly and would like to stay as a part of it. This case is the best form of employees' commitment to the organization. Those are the loyal employees having self commitment to the organization of whom all employers dream. Such employees show positive attitude to the job and they are ready to make more effort when needed (Bayram, 2005:132). Autonomy in the job, clarity and meaningfulness of the task, image of the job, qualities required for the job, attitude, behavior and approaches of the manager, participation in management are the prerequisites of the emotional commitment (Kurşunoğlu, et al., 2010:102).

For the maintenance of commitment which forms the second factor reliability coefficient (Alpha) $\alpha=0.724$, total rate of the explained variance was appointed as $\% 22$, 15. Continuance commitment indicates the degree with which an employee believes that leaving the organization would be costly (Yüceler, 2009:448; Buchko, et al., 1998: 110). Specialization obtained within the working period, social relations with the colleagues, seniority, retirement rights can be regarded as personal investment of an employee (Obeng and Ugboro, 2003: 84; Taşkın and Dilek, 2010:39). In the continuance commitment emotions are considered to play a slight role in commitment to the organization. Continuance commitment is maintaining the membership to the organization because of the consideration that leaving the organization may cost a lot (Meyer and Allen, 1997:11; Yüceler, 2009: 448). The person with continuance commitment has the idea that he would have fewer options in case of leaving the organization. Some of employees stay in the organization as they could not find another job whereas some have particular important reasons such as health, family matters or being close to the retirement rather than loving the job. Besides bad organizational habits they show, negative attitudes create serious problems for the managers (Bayram, 2005:133). In continuance commitment factors such as age, working period, career satisfaction, intention to leave, education, marital status and alternative job possibilities play a determinant role (Kurşunoğlu, et al., 2010:103). It can be indicated continuance commitment is a dimension which is not desired to be experienced in an organization. 
Table 3. Factors Analysis Results of Job Satisfaction

\begin{tabular}{|c|c|c|c|c|}
\hline Construct and items & Factor Loadings & $\begin{array}{l}\text { Eigen } \\
\text { values }\end{array}$ & $\begin{array}{l}\text { The Ratio of } \\
\text { Variance }(\%)\end{array}$ & Cronbach's alpha \\
\hline \multicolumn{5}{|c|}{ Factor 1: Management Style and Manager Satisfaction (MSMS) } \\
\hline •MSMS1 & 0,877 & & & \\
\hline •MSMS2 & 0,872 & & & \\
\hline •MSMS3 & 0,792 & & & \\
\hline$\cdot$ MSMS4 & 0,748 & & & \\
\hline$\cdot$ MSMS5 & 0,715 & & & \\
\hline •MSMS6 & 0,701 & & & \\
\hline •MSMS7 & 0,695 & 10,23 & 26,63 & 845 \\
\hline •MSMS8 & 0,681 & & & \\
\hline •MSMS9 & 0,621 & & & \\
\hline •MSMS10 & 0,612 & & & \\
\hline •MSMS11 & 0,597 & & & \\
\hline \multicolumn{5}{|c|}{ Factor 2: Work Satisfaction (The Work Itself) (WS) } \\
\hline -WS1 & 0,717 & & & \\
\hline •WS2 & 0,693 & & & \\
\hline •WS3 & 0,651 & 4,18 & 10,88 &, 814 \\
\hline •WS4 & 0,593 & & & \\
\hline •WS5 & 0,542 & & & \\
\hline \multicolumn{5}{|c|}{ Factor 3: Working Conditions Satisfaction (WCS) } \\
\hline •WCS1 & 0,722 & & & \\
\hline •WCS2 & 0,648 & & & \\
\hline •WCS3 & 0,551 & 3,53 & 9,18 &, 823 \\
\hline •WCS4 & 0,522 & & & \\
\hline -WCS5 & 0,501 & & & \\
\hline \multicolumn{5}{|c|}{ Factor 4: Development Facilities and Promotion Satisfaction (DFPS) } \\
\hline •DFPS1 & 0,717 & & & \\
\hline •DFPS2 & 0,618 & 2,57 & 6,69 &, 801 \\
\hline -DFPS3 & 0,541 & & & \\
\hline \multicolumn{5}{|c|}{ Factor 5: Control And Responsibility Satisfaction (CRS) } \\
\hline •CRS1 & 0,734 & & & \\
\hline •CRS2 & 0,597 & 2,22 & 5,77 & ,788 \\
\hline$\cdot \mathrm{CRS} 3$ & 0,542 & & & \\
\hline \multicolumn{5}{|l|}{ Factor 6: Salary Satisfaction (SS) } \\
\hline •SS1 & 0,792 & 1,82 & 4,73 &, 803 \\
\hline$\cdot \mathrm{SS} 2$ & 0,745 & & & \\
\hline \multicolumn{5}{|l|}{ Factor 7: Colleagues Satisfaction (CS) } \\
\hline •CS1 & 0721 & 1,15 & 2,99 &, 817 \\
\hline$\cdot \mathrm{CS} 2$ & 0,694 & & & \\
\hline Kaiser-Meyer-Olkin Value & & & &, 874 \\
\hline Bartlett's test of sphericity & & & & 1917,$9 ; \mathrm{sig}=0,00$ \\
\hline The Ratio of Total Variance & & & & $\% 66,87$ \\
\hline Overall Cronbach's Alpha & & & &, 845 \\
\hline
\end{tabular}

Reliability coefficient of normative commitment which is the third and the last factor was found (alpha) $\alpha=0.825$ and total variance explaining rate was appointed as 7 , $85 \%$. Normative commitment shows employees' faith in their responsibilities to their organizations (Gül, 2002: 45). This dimension of the organizational commitment leads employees believing that they have particular responsibilities and liabilities and therefore they have to stay in the organization (Wasti, 2002: 525; Meyer and Allen, 1997:11). Namely people stay in the organization due to feeling of gratitude. The reason underlying this feeling is that managers employ them in a period when they really need a job or the value judgment as to the effect that keeping the present job is the best thing. Such people think that organization behaves them well and therefore working more in the organization is their responsibility (Bayram, 2005:133).

As a result of the reliability test applied to the job satisfaction scale, it was observed one proposition lowered the reliability level and therefore was excluded from the research. After removing the related proposition, the reliability was found (Cronbach alpha) $\alpha=, 845$. This value shows that the reliability of the scale is quite high (Nunnally, 1978). Moreover, the scale's reliability coefficient related to subdimensions was specified as acceptable (Cronbach's alpha coefficients). As a result of the factor analysis applied to the job satisfaction scale, it was determined that job 
satisfaction dimensions were gathered under seven dimensions. Total variance rate that these seven factors explained was $66,87 \%$. Each one of the factors was named after their own items. Scale's KMO value $(, 874)$ and Bartlett test $(1917,9$; sig=0, 00) result show that the scale is suitable to carry out factor analysis (Hair et al. 1995).

First factor (management style and manager satisfaction) is composed of eleven propositions in total, and explains $26,23 \%$ of the total variance with the highest rate. Second factor (work satisfaction) explains $10,88 \%$ of the variance and it is composed of five suppositions. Third factor (working conditions satisfaction) composed of five suppositions explains $9,18 \%$ of the variance. Fourth factor (development facilities and promotion satisfaction) explains $6,69 \%$ of the variance and be composed of three suppositions. Fifth factor (control and responsibility satisfaction) explains 5,57\% of the variance and composed of three suppositions. Sixth factor (salary satisfaction) explains $4,73 \%$ of the variance and there are two suppositions under it. And lastly, seventh factor (colleagues satisfation) explains $2,99 \%$ of the total variance and be composed of two suppositions.

\section{The Relationship between Job Satisfaction \& Organizational Commitment}

The correlations of the scale scores are calculated in order to examine the relationship between job satisfaction and organizational commitment dimensions. As a result of the correlation analysis, it was found out that the highest correlation with emotional commitment is between management style and manager satisfaction $(r=$ 722, $\mathrm{p}<0.05)$. According to this result, there is a strong and positive relationship between emotional attachment, management style and manager satisfaction. So, as the management style and manager satisfaction increase, organizational commitments of the employees increase, too. It is seen that there is a meaningful and positive relationship between emotional commitment and all dimensions that creates the job satisfaction. According to the findings obtained from the correlation analysis, there is a strong and positive relationship between emotional commitment and overall job satisfaction $(r=$ $723, \mathrm{p}<0.05)$.

Table 4: Correlation Analysis

\begin{tabular}{|c|c|c|c|c|c|c|c|c|c|c|c|}
\hline & 1 & 2 & 3 & 4 & 5 & 6 & 7 & 8 & 9 & 10 & 11 \\
\hline $1 . \mathrm{AC}$ & 1 & & & & & & & & & & \\
\hline 2.CC &,$- 573(* *)$ & 1 & & & & & & & & & \\
\hline 4.MSMS &, $722(* *)$ &,$- 572(* *)$ &, $564(* *)$ & 1 & & & & & & & \\
\hline 5.WS &, $490(* *)$ &,$- 295(* *)$ &, $376(* *)$ &, $488(* *)$ & 1 & & & & & & \\
\hline 6.WCS &, $688(* *)$ &,$- 611(* *)$ & ,491(**) &, $700(* *)$ &, $529(* *)$ & 1 & & & & & \\
\hline 9.SS &, $615(* *)$ &,$- 487(* *)$ &, $465(* *)$ &, $630(* *)$ &, $408(* *)$ &, $598(* *)$ &, $600(* *)$ &, $552(* *)$ & 1 & & \\
\hline 10.CS &, $663(* *)$ &,$- 524(* *)$ & ,488(**) &, $715(* *)$ &, $513(*)$ &, $686(* *)$ &, $617(* *)$ &, $610(* *)$ & ,641(*) & 1 & \\
\hline 11.OV* &, $723(* *)$ &,$- 538(*)$ &, $556(* *)$ &, $750(* *)$ &, $606(* *)$ &, $745(* *)$ &, $706(* *)$ &, $696(* *)$ &, $692(* *)$ &, $748(* *)$ & 1 \\
\hline \multicolumn{12}{|c|}{$\begin{array}{l}\text { * OV (Overall Satisfaction) Overall job satisfaction is determined by taking the arithmetic mean of job satisfaction dimensions. } \\
* * \text { Correlation is significant at the } 0.01 \text { level (2-tailed). }\end{array}$} \\
\hline
\end{tabular}

A statistically significant negative relationship was found between all dimensions that create the job satisfaction and continuance commitment which constitutes another dimension of organizational commitment. The highest correlations with the continuance commitment is between working conditions satisfaction $(r=-611, \mathrm{p}<0.05)$ and the management style and manager satisfaction $(r=-572, \mathrm{p}<0.05)$. It was demonstrated 
that there is a strong and negative relationship between attendance commitment and these two dimensions. According to this result, in the event that the satisfaction with the working conditions, the management and the manager increases, attendance commitment level decreases significantly. In summary, it is considered there exists a meaningful and negative $(r=-, 538, \mathrm{p}<0.05)$ relationship between attendance commitment and general job satisfaction.

It is determined that there is a statistically significant and positive relationship between normative commitment which is the third and final dimension of organizational commitment, and all the dimensions that create job satisfaction. The strongest correlation between normative commitment and job satisfaction dimensions is between management style \& manager satisfaction $(r=564, \mathrm{p}<0.05)$ and development \& promotion opportunities satisfaction $(r=531, \mathrm{p}<0.05)$. When the employees' management / manager satisfaction and development / promotion opportunities satisfaction increase, normative commitment shows positive increase. Correlation analysis results show that there is a meaningful and positive relationship $(r=556, \mathrm{p}$ $<0.05$ ) between normative commitment and overall job satisfaction. In general sense, it is seen that the job satisfaction subscale having the highest degree of relationship with all the sub-dimensions of organizational commitment is management style and manager satisfaction scale.

\section{Clustering of the Employees In Line with Their Organizational Commitment and Job Satisfaction Levels}

Categorizing organizational commitment and job satisfaction levels is considered to be more descriptive so as to understand the demographic features of job satisfaction and organizational commitment. Therefore clustering analysis is commonly used for categorizing organizational commitment and job satisfaction levels of employees working in different departments. Cluster analysis is one of the multivariate statistical methods frequently utilized for classifying ungrouped data by similarity. Multivariate analysis can be used for different aims because of including various analyses. The primary aim of cluster analysis is to categorize the individuals or objects by considering their similarities or differences based on their features. In cluster analysis distance measurements, correlation measurements, or similarity measurements of categorical data are used in order to determine the similarities between them by calculating the value of all observed individuals or objects on all observed variables (Kalayc1, 2006: 349).

In order to carry out the cluster analysis, SPSS program was used. This program provides three options to carry out the cluster analysis. These are hierarchical cluster, kmeans cluster and two-step cluster analysis. All these analyses methods have particular weak and strong aspects compared to each other. For example, in hierarchical cluster analysis the cluster number is specified by benefiting from the analysis outputs after the analysis is over whereas in k-means cluster analysis, the number should be determined at the beginning in order to initiate the analysis. However; when there are excessive number of data and variables in a data set, it is impossible to determine the exact value. In addition, in hierarchical cluster analysis, the analysis is completed by checking the data set which causes problems emerging in the decomposition process at the beginning and continuing until the end. K-means cluster analysis check the data set more than once so it has an advantage to solve the problems appearing at the beginning of the 
analysis before passing the next phases. Two-step cluster analysis' strongest aspect is the determination of the cluster numbers automatically by the analysis itself (Budayan et al. 2007:143).

Table 4. Cluster Analysis on the Classification of Organizational Commitment and Job Satisfaction Levels of Employees

\begin{tabular}{|c|c|c|c|c|c|c|}
\hline & \multirow[b]{2}{*}{$\mathrm{n}$} & \multirow[b]{2}{*}{$\%$} & \multicolumn{3}{|c|}{ Organizational Commitment Score } & \multirow{2}{*}{$\begin{array}{c}\text { Job Satisfaction } \\
\text { Score }\end{array}$} \\
\hline & & & $\begin{array}{c}\text { Affective } \\
\text { Commitment } \\
\text { Mean }\end{array}$ & $\begin{array}{c}\text { Continuance } \\
\text { Commitment Mean }\end{array}$ & $\begin{array}{c}\text { Normative } \\
\text { Commitment Mean }\end{array}$ & \\
\hline Group 1 & 327 & $\% 39,8$ & 4,03 & 2,37 & 3,81 & 3,87 \\
\hline Group 2 & 356 & $\% 43,4$ & 3,54 & 3,26 & 3,48 & 3,52 \\
\hline Group 3 & 138 & $\% 16,8$ & 2,25 & 3,92 & 2,68 & 2,41 \\
\hline
\end{tabular}

To categorize the employees working in different departments according their organizational commitment and job satisfaction levels, two-step cluster analysis was used and related data were obtained from the scale. As a result of the cluster analysis, employees were classified into three groups according to their organizational commitment and job satisfaction levels. First cluster is composed of 327 people and comprises $39,8 \%$ of the total participants. It is observed the affective commitment average of those forming the first group is $\bar{x}=4,03$ continuance commitment average is $\overline{\mathrm{x}}=2,37$, normative commitment average is $\overline{\mathrm{x}}=3,81$ and job satisfaction average is $\overline{\mathrm{x}}=3$, 87. These values show that employees have high level of organizational commitment and job satisfaction. In line with these results, first cluster was named as "very positive organizational result".

Second cluster is composed of 256 people and forms the $43,4 \%$ of the total participants. Second cluster is also the one which contains the highest number of participants. Examining the organizational commitment (AC: $\bar{x}=3,54 ; C C: \bar{x}=3,26$; NC: $\bar{x}=3,48)$ and job satisfaction level $(\bar{x}=3,52)$ of those in the second cluster, it is seen that it is lower than those of the first cluster; however, it shows a positive chart in general sense. The participants in this cluster also have a high organizational commitment and job satisfaction level. But as organizational commitment and job satisfaction levels of employees in the second cluster are lower than those of the first cluster, it is named as "positive organizational result".

Finally, the third group consists of 138 people, and it constitutes $16.8 \%$ of the total participants. The third group is the one with the lowest participation. When the organizational commitment ( $\mathrm{AC}: \overline{\mathrm{x}}=2,25 ; \mathrm{CC}: \overline{\mathrm{x}}=3,92 ; \mathrm{NC}: \overline{\mathrm{x}}=2,68)$ and job satisfaction $(\overline{\mathrm{x}}=2,41)$ levels of participants forming the third group are examined, it is seen that their organizational commitment and job satisfaction are very low. In other words, the common feature of participants that form the third group is having a very low organizational commitment and not being satisfied with the job. Because of this negative image, the third group is named as the "negative organizational result".

\section{Demographic Variables and United Categories Effecting Organizational Outcomes}

CHAID analysis was applied to organizational outcomes of the cluster analysis so as to determine the demographic variables that affect organizational outcomes in order of importance, to create subclasses and to determine the positive and negative organizational consequences typology. In CHAID analysis, organizational outcomes 
obtained from the cluster analysis results were used as dependent variables (consisting of three categories), and demographic variables were used as independent variables, demographic variables affecting the organizational outcomes are shown in the diagram below (Figure 1). In this diagram, dependent and independent variables were classified in the form of tree structures, and they provide detailed information on demographic variables that affect organizational outcomes.

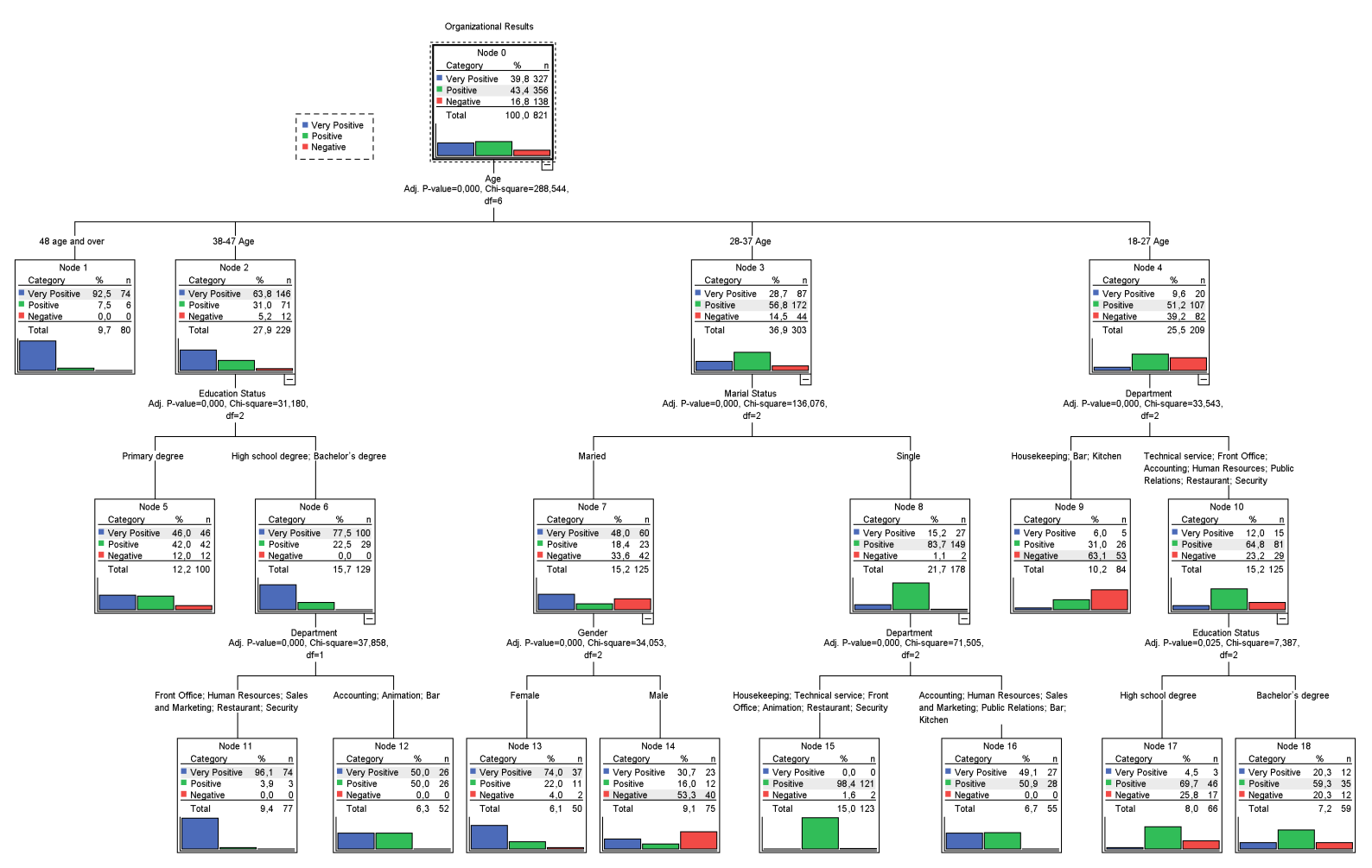

Figure1: CHAID Analysis Results

In Figure 1, CHAID analysis results of demographic variables that affect the attitudes of organizational commitment and job satisfaction of employees in accommodation business are presented. Demographic variables that influence job satisfaction and organizational commitment were determined in order of importance. According to the CHAID analysis, age variable takes the first place among the demographic variables that are effective on employees' job satisfaction and organizational commitment $\left[\chi_{(6)}^{2}=288,544 ; p=0.000\right]$. Unlike other variables, the age variable has a dominant influence on employees' job satisfaction and organizational commitment levels. As average age of employees' increases, more statistically significant increase is observed in job satisfaction and organizational commitment levels. All 48 years and older employees (Node 1) were found out to have high levels of job satisfaction and organizational commitment. 39.2\% of employees (Node 4) in the age range of 18-27 showed a negative attitude in terms of job satisfaction and organizational commitment.

In the job satisfaction and organizational commitment levels of department employees between the ages 38-47 (Node 2), educational variable constitutes the dominant influence $\left[\chi_{(2)}^{2}=31,180 ; p=0.000\right]$. These results show that $100 \%$ of $38-47$ year-old high school and university graduate employees (Node 6) have positive job 
satisfaction and organizational commitment attitudes. $12 \%$ of the $38-47$ year-old primary school graduate employees (Node 5) have negative job satisfaction and organizational commitment attitudes. This indicates that with an increase in the education level of employees aged between 38-47 years, a positive increase in job satisfaction and organizational commitment levels occurs. The department variable affects 38-47 year-old high school and university graduate employees' (Node 6) job satisfaction and organizational commitment levels $\left[\chi_{(1)}^{2}=37,858 ; p=0.000\right]$. Based on these results, the 38-47 year-old employees (No. 12) with a high school or bachelor's degree and working in accounting, animation and bar departments have lower job satisfaction and organizational commitment levels than 38-47 year-old high school or university graduate employees in other departments (No. 11).

"Marital status" seems to be the most effective variable on 28-37 year-old employees' (Node 3) job satisfaction and organizational commitment attitudes, $\left[\chi_{(2)}^{2}=136,076 ; p=0.000\right]$. According to this finding, almost all 28-37 year-old single employees (98.9\%) (Node 8) have positive attitude towards job satisfaction and organizational commitment; however, $33.6 \%$ of employees who are married in the same age group (Node 7) have a negative attitude. With a change in marital status of 28-37 year-old employees (Note 3), job satisfaction and organizational commitment levels change significantly. The variable "Gender" is statistically effective on 28-37 year-old married employees' (Node 7) job satisfaction and organizational commitment attitudes $\left[\chi_{(2)}^{2}=34,053 ; p=0.000\right]$. Based on these results, more than half of (53.3\%) 28-37 yearold male and married employees (No. 14) have a negative attitude in terms of job satisfaction and organizational commitment. On the other hand, only 4\% of 28-37 yearold female and married employees (No. 13) have a negative attitude in terms of job satisfaction and organizational commitment whereas $96 \%$ of them have a positive attitude. This result reveals that the variable "gender" creates quite different effects on 28-37 year-old married employees' job satisfaction and organizational commitment levels. In addition, the variable "department" constitutes statistically significant differences on 28-37 year-old single employees' (No 8) job satisfaction and organizational commitment attitudes, $\left[\chi_{(2)}^{2}=71,505 ; \mathrm{p}=0.000\right]$.

"The department being worked in" was found to be the most effective variable on job satisfaction and organizational commitment attitudes of employees (Node 4) in the age range of $18-27\left[\chi_{(2)}^{2}=33,543 ; p=0.000\right]$. The variable "department" was grouped into two subsets. According to this finding, $63.1 \%$ of housekeeping bar and kitchen staff (No. 9) in the age range of 18-27, show a negative attitude in terms of job satisfaction and organizational commitment. In other words, 18-27 aged employees in housekeeping bar and kitchen departments are the most crowded group consisting of employees with low level-job satisfaction and organizational commitment. $23.2 \%$ of $18-27$ year-old employees in the technical service, front office, accounting, human resources, public relations, and restaurant and security departments have a negative attitude in terms of job satisfaction and organizational commitment. It was found out that job satisfaction and organizational commitment levels of 18-27 year-old employees in these departments statistically differ in line with their education levels $\left[\chi_{(2)}^{2}=7,387 ; p=0.025\right]$. Undergraduate and high school degree has been found to be effective on this group (Node 10). Accordingly, from high school level to undergraduate level, job satisfaction and organizational commitment levels of the employees in Node 10 increase and constitute a statistically significant difference. 


\section{Conclusion and Discussion}

In the accommodation businesses in tourism sector, which is a labor-intensive sector, the importance of the labor force is much higher than in other sectors. In a sector where the customers who purchase the service and the employees who serve it are in an integrated and face-to-face relationship, providing satisfactory services and ensuring customer satisfaction are impossible for an employee with low job satisfaction and organizational commitment. In this context, employee's job satisfaction and organizational commitment, feelings and thoughts during his service may affect the service quality (Toker, 2007: 94). Hospitality industry strongly depends on the human factor. Human resources are one of the most important factors that play a decisive part in enhancing the organizational image (AlBattat et al., 2014: 45).

When the current literature is investigated, it is understood that there is a high employee turnover rate in accommodation businesses (Üngüren and Çevirgen, 2014; Cheng and Brown, 1998; Birdir, 2002; Woods, 1997; Kuria et al., 2012; Ghiselli et al., 2001; Hemdi and Nasurdin, 2005; Lam et.al., 2001; Dipietro and Condly, 2007). The high employee turnover rate in the accommodation businesses shows the importance of the job satisfaction and organizational commitment concepts in such kind of businesses (Tracey and Hinkin, 2008; Karsh, et.al., 2005; March and Simon, 1958).

Over the past several decades, job satisfaction and organizational commitment have been recognized as important concepts due to their importance and contribution to organizational outcomes (effectiveness, performance, turnover, turnover intention, absenteeism, burnout etc.). The relationship between job satisfaction and organizational commitment has been studied frequently. Previous research indicates that there is a high correlation between these two concepts (Tarigan and Ariani, 2015: 22).

As a result of the research, it was determined that there is a strong positive relationship between job satisfaction and organizational commitment of employees in accommodation businesses. Management style and manager satisfaction seems to be the most important job satisfaction subscale, which is quite related to employees' organizational commitment levels. The higher management style and manager satisfaction department employees have the higher organizational commitment levels they reach. The variable "Salary" was seen as the lowest dimension of job satisfaction related the organizational commitment. These results indicate the importance of managers' relationship with the employees and the management style in terms of organizational commitment. The fact that salary is the least related variable with organizational commitment suggests that for creating an efficient and effective working environment, human relationships are more important than financial interests. Employees' satisfaction with the managers, communicating with them easily, the confidence to be able to easily obtain the technical support they need in fulfilling the tasks expected from them are effective in showing emotional commitment to the organization. According to these results, employees' satisfaction with the management style and managers is a very important factor in improving their organizational commitment. In other words, it can be said managers and their management style play a key role in increasing or decreasing employees' organizational commitment.

Also, researches carried out in different sectors and areas reveal that demographic factors are effective in employees' job satisfaction and organizational commitment (Pourghaz et al., 2011; Mathieu and Zajac, 1990; Igbal, 2010; Salami, 2008; Elizur, 
2001; Azeem, 2010; Angle and Perry 1981; Luthans et al. 1987; Bowen et al. 1994; Clark, 1997; Shields and Price, 2002). But any detailed research, which covers the significance levels and all possible hierarchy, on impacts of demographic variables in job satisfaction and organizational commitment could not be found very common. In this context, the impact of demographic characteristics of employees in accommodation businesses on job satisfaction and organizational commitment has been demonstrated by CHAID analysis.

The variable "Age", one of the demographic variables in the survey, has the dominant effect on employees' job satisfaction and organizational commitment levels. As the employees' age increase, their job satisfaction and organizational commitment levels increase, as well. When the research results are analyzed in this context, it is seen that there is generally a positive correlation between age and satisfaction. This could be resulting from the harmony increasing with experience and age. On the other hand, younger employees are likely to be unsatisfied when they first start work because of their high expectations for the promotion and other working conditions (Toker, 2007).

According to CHAID analysis results;

- The variable "Age" was found to be the dominant demographic variable that has influence on job satisfaction and organizational commitment attitudes of employees in accommodation businesses. With the increase in employees' average of age a statistically significant increase in job satisfaction and organizational commitment levels occurs.

- All 48 year-old and older employees were found out to be satisfied with the job with a high organizational commitment.

- "The department being worked in" was determined to be the most influential variable on job satisfaction and organizational commitment attitudes of employees in the age range of 18-27.

- More than half of the employees between the ages 18-27 and working in housekeeping, bar and kitchen departments are not satisfied with the job and do not feel an emotional commitment to the organization.

- "Marital status" was determined to be the dominant variable on job satisfaction and organizational commitment attitudes of employees in the age range of 2837.

- It has been demonstrated that marital status change of 28-37 year-old employees significantly differs their job satisfaction and organizational commitment attitudes. Single employees between 28-37 ages are satisfied with the job and feel commitment to the organization.

- $33.6 \%$ of the married employees who are in the age range of 28-37 seem to be not satisfied with their jobs and do not feel an emotional commitment to the organization.

- The variable "Gender" was found to have a dominant influence on the job satisfaction and organizational commitment attitudes of 28-37 year-old married employees.

- More than half of male and married employees in the age range of 28-37 are not satisfied with their jobs and do not feel an emotional commitment to the organization. 
- $96 \%$ of married and female employees in the age range of $28-37$ feel satisfied with the job and commitment to the organization

- The variable "Education" is determined to have a dominant effect on job satisfaction and organizational commitment levels of department employees in the age range of 38-47. With an increase in the education level of 38-47 year-old employees, it has been concluded that job satisfaction and organizational commitment levels increase in the positive direction.

- All of the 38-47 year-old high school and university graduate employees seem to have a positive attitude towards job satisfaction and organizational commitment.

- $12 \%$ of 38-47 year-old primary school graduate employees show negative attitude towards job satisfaction and organizational commitment.

- Job satisfaction and organizational commitment levels of high school and bachelor's degree graduate employees between 38-47 years-old show statistically significant differences according to the department they work in.

As a result of the research, the dominant groups that have a negative attitude towards job satisfaction and organizational commitment are "18-27 year-old housekeeping, bar and kitchen staff" and "married male employees in the age range of 28-37". Employees who display a totally positive attitude towards job satisfaction and organizational commitment are generally gathered under two categories: The first category consisting of 38-47 year-old high school and bachelor's degree graduate employees and the second category consisting of employees at the age of 48 and over

Within the scope of the literature, it is seen that many studies have been carried out on employees' job satisfaction and organizational commitment based on the demographic base. However, a research examining which demographic variables have relatively more influence on job satisfaction and organizational commitment and testing the finding with a comprehensive model could not be found. Hence, the impact of demographic variables on job satisfaction and organizational commitment are shown in detail, covering the relationships and all possible hierarchy between predictor and predicted variables by applying CHAID in this study. The obtained results show that CHAID analysis can be effectively utilized in the field of social sciences due to the fact that it creates a homogenous nodes in heterogeneous data sets, creates maximum rules for classifying people, continuous and categorical data can be included into the model at the same time and it provides visualization by evaluating the relationships between dependent and independent variables in detail. 


\section{References}

Agho, A., Mueller, C. \& Price, J. (1993). Determinants of Employee Job Satisfaction: An Empirical Test of a Causal Model, Human Relations, 46 (8): 1007-1027.

Ahmad, N. \& Oranye, N.O. (2010). Empowerment, Job Satisfaction and Organizational Commitment: A Comparative Analysis of Nurses Working in Malaysia and England, Journal of Nursing Management, 18: 582-591.

AlBattat, A.R., Ahmad Puad Mat Som, A.P.M. \& Helalat A. S. (2014). Higher Dissatisfaction Higher Turnover in the Hospitality Industry, International Journal of Academic Research in Business and Social Sciences, 4(2): 45-52.

Allen, N. J. \& Meyer, J. P. (1990). The Measurement and Antecedents of Affective, Continuance and Normative Commitment to the Organization, Journal of Occupational Psychology, 63(4): 1-18.

Allen, N.J. \& Meyer, J.P. (1996). Affective, Continuance and Normative Commitment to the Organisation, an Examination of Construct Validity. Journal of Vocational Behaviour, 49: 252-276.

Angle, H. \& Perry, J. (1981). An Empirical Assessment of Organizational Commitment and Organizational Effectiveness, Administrative Science Quarterly, 26: 1-14.

Avc1, N. \& Küçükusta, D. (2009). Konaklama İşletmelerinde Örgütsel Öğrenme, Örgütsel Bağlılık ve İşten Ayrılma Eğilimi Arasındaki İlişki, Anatolia: Turizm Araştırmalart Dergisi, 20(1): 33-44.

Avşar, A.Ş. \& Yalçın, S. (2015). Determining the Parental Variables That Explain Students' Reading Success by Using CHAID Analysis, Education and Science, 40(179): $1-9$.

Azeem, S.M. (2010). Job Satisfaction and Organizational Commitment among Employees in the Sultanate of Oman, Psychology, 1: 295-299.

Balay, R. (2000). Yönetici ve Öğretmenlerde Örgütsel Bağlılık, Nobel Yayın Evi: Ankara.

Bansal H.S, Mendelson M.B, \& Sharma B. (2001). The Impact of Internal Marketing Activities on External Marketing Outcomes, Journal of Quality Management, 6(1):61-76.

Batıgün, A.D. \& Şahin, N.H. (2006). İş Stresi ve Sağlık Psikolojisi Araştırmaları İçin İki Ölçek: A-Tipi Kişilik ve İş Doyumu, Türk Psikiyatri Dergisi, 17(1): 32-45.

Bayram, L. (2005). Yönetimde Yeni Bir Paradigma: Örgütsel Bağlılık, Sayıştay Dergisi, 59: 125-139.

Biçer, İ.H., Erçek, M., Küskü, F. \& Çakmak, A.F (2009). Örgütsel Bağl1lığın Duygusal Bileşenleri: Türk Kamu Kuruluşunda Kapsamlı Bir Yapısal Denklem Modeli, ITÜ Mühendislik Dergisi, 8(4): 187-198.

Birdir, K. (2002), General Manager Turnover and Root Causes, International Journal of Contemporary Hospitality Management, 14(1): 43-47.

Bowen, C.F., Radhakrishna, R. \& Keyser, R. (1994). Job Satisfaction and Commitment of 4-H Agents, Journal of Extension, 32(1): 1-22.

Boylu, Y., Pelit, E. \& Güçer, E. (2007). Akademisyenlerin Örgütsel Bağl1lık Düzeyleri Üzerine Bir Araştırma, Finans Politik \& Ekonomik Yorumlar, 44(511): 55-74. 
Börü, D. \& Güneşer, B. (2005). Liderlik Tarzının Çalışanın İş Tatmini ile İlişkisi ve Lidere Olan Güvenin Bu İlişkideki Rolü, Hacettepe İktisadi ve İdari Bilimler Dergisi, 23(1): 135-156

Buchko, A.A, Weinzimmer, L.G \& Sergeyev, A.V. (1998). Effects of Cultural Context on the Antecedents, Correlates, and Consequences of Organizational Commitment: A study of Russian Workers, Journal of Business Research, 43: 109-116.

Budayan, C., Dikmen, İ. \& Birgönül, M.T. (2007). Türk İnşaat Sektöründe Stratejik Grup Analizi, 4. İnşaat Yönetimi Kongresi Bildiriler Kitabı (139-148)

Cevrioğlu, E. (2007). Lider-Üye Etkileşimi İle Bireysel ve Örgütsel Sonuçlar Arasındaki İlişki: Ampirik Bir İnceleme, Doktora Tezi, Afyonkarahisar Kocatepe Üniversitesi Sosyal Bilimler Enstitüsü, Afyonkarahisar.

Chen LH. (2008). Job Satisfaction among Information System (IS) Personel, Computers in Human Behavior, 24: 105-118.

Cheng, A.\& Brown, A. (1998). HRM Strategies and Labour Turnover in the Hotel Industry: A Comparative Study of Australia and Singapore. The International Journal oh Human Resource Management, 9(1): 136 -154.

Clark, A.E. (1997). Job Satisfaction and Gender: Why are Women so Happy at Work? Labour Economics, 4:341-372.

Cohen, A. (1993). Organisational Commitment and Turnover: A Meta-Analysis, Academy of Management Journal, 36:1140-1157.

Cooper-Hakim, A. \&Viswesvaran, C. (2005). The Construct of Work Commitment: Testing an Integrative Framework, Psychological Bulletin, 131(2): 241-259.

Crossman, A. \& Abou-Zaki, B. (2003). Job Satisfaction And Employee Performance Of Lebanese Banking Staff, Journal of Managerial Psychology, 18 (4): 368-376.

Currivan, D.B. (1999). The Causal Order of Job Satisfaction and Organizational Commitment in Models of Employee Turnover, Human Resource Management Review, 9(4): 495-524.

Çekmecelioğlu H. (2006). İş Tatmini Ve Örgütsel Bağlılık Tutumlarının İşten Ayrılma Niyeti Ve Verimlilik Üzerindeki Etkilerinin Değerlendirilmesi: Bir araştırma. İş, Güç Endüstri İlişkileri ve İnsan Kaynakları Dergisi, 8(2): 1303-2860.

Davis K. (1988). İşletmelerde İnsan Davranışı Örgütsel Davranış, (Çeviri: Kemal Tosun), İstanbul Üniversitesi İşletme Fakültesi, İstanbul.

DeLoria, J.E. (2001). A Comparative Study of Employee Commitment: Core and Contract Employees in a Federal Agency, Dissertation Of DOctor Philosophy, Faculty of the Virginia Polytechnic Institute and State University, USA (http://scholar.lib.vt.edu/theses/available/etd10212001152609/unrestricted/dissdf8 .pdf Erișim Tarihi 15.01.2011)

Dilek, H. (2005). Liderlik Tarzlarının Ve Adalet Algısının; Örgütsel Bağlılık, İş Tatmini Ve Örgütsel Vatandaşlık Davranışı Üzerine Etkilerine Yönelik Bir Araştırma, Doktora Tezi, Gebze Yüksek Teknoloji Enstitüsü Sosyal Bilimler Enstitüsü, Gebze.

Dipietro, R.B. \& Condly, S.J. (2007). Employee Turnover in the Hospitality Industry. An Analysis Based on the CANE Model of Motivation, Journal of Human Resources in Hospitality \& Tourism, 6(1): 1 -22 
Dirani, K.,M. \& Kuchinke, K.P. (2011). Job Satisfaction and Organizational Commitment: Validating the Arabic Satisfaction and Commitment Questionnaire (ASCQ), Testing the Correlations, and Investigating the Effects of Demographic Variables in the Lebanese Banking Sector,The International Journal of Human Resource Management, 22(5): 1180-1202.

Doğan, S. \& S. Kılıç (2007). Örgütsel Bağlılığın Sağlanmasında Personel Güçlendirmenin Yeri Ve Önemi, Erciyes Üniversitesi İktisadi ve İdari Bilimler Fakültesi Dergisi, 29: 37-61.

Doğan, İ . (2003). Holştayn Irkı İneklerde Süt Verimine Etki Eden Faktörlerin CHAID Analizi İle İncelenmesi, Ankara Üniversitesi Veterinerlik Fakültesi Dergisi, 50:65-70.

Elizur, D. \& Koslowsky, M. (2001). Values and Organisational Commitment, International Journal of Manpower, 22: 593-599.

Erbaş, S. \& Güneş, A. (1998). Chaid Analizi, İstatistik Konferansı Bildiri Kitabı, Ankara.

Feinstein A.H. \& Vondrasek D. (2001). A study of Relationships Between Job Satisfaction and Organizational Commitment among Restaurant Employees, Journal of Hospitality, Tourism and Leisure Science, 1(4): 1-20.

Fosam E.B, Grimsley, M.F.J. \& Wisher SJ. (1998). Exploring Models for Employee Satisfaction - with Particular Reference to a Police Force, Total Quality Management, 9: 235-247.

Freund, A. (2005). Commitment and Job Satisfaction as Predictors Turnover Intentions among Welfare Workers, Administration in Social Work, 29(2): 5-21.

Friday, S.S. \& Friday, E. (2003). Racioethnic Perceptions of Job Characteristics and Job Satisfaction, Journal of Management Development, 22 (5): 426-442.

Gaertner S. (1999). Structural Determinants of Job Satisfaction and Organizational Commitment in Turnover Models, Human Resource Management Review, 9(4):479-493.

George J.M. (1992). The Role of Personality in Organizational Life: Issues and Evidence, Journal of Management, 18(2): 185-213.

Ghazzawi, I., \& Smith Y. (2009). Crafting the Whole Employee: Job Satisfaction, Job Commitment, and Faith-A New Conceptual Framework and Research Agenda, The Business Review Cambridge. 12(2):300-309.

Ghiselli, R.F., LaLopa J.M. \& Bai, B. (2001). Job Satisfaction, Life Satisfaction and Turnover Intent among Food-Service Managers, Cornell Hotel and Restaurant Administration Quarterly, 42(2): 28-37.

Gül, H. (2002). Örgütsel Bağlılık Yaklaşımlarının Mukayesesi ve Değerlendirmesi, Ege Akademik Bakış, 2(1): 37-56.

Güneş, İ., Bayraktaroğlu, S.\& Kutanis, R.Ö. (2009). Çalışanların Örgütsel Bağlılık ve Tükenmişlik Düzeyleri Arasındaki İlişki: Bir Devlet Üniversitesi Örneği, Süleyman Demirel Üniversitesi İktisadi ve İdari Bilimler Fakültesi Dergisi, 14(3):481-497.

Hair, J.F., Anderson, R.E., Tahtam, R.L. \& Black, W.C. (1995). Multivariate Data Analysis (4th. Ed.). USA: Prentice-Hall, Inc. 
Harrison D.A., Newman, D. \& Roth, P.L. (2006). How Important are Job Attitudes? Metaanalytic Comparisons of Integrative Behavioral Outcomes and Time Sequences, Academy of Management Journal, 49:305-325.

Hemdi, M.A. \& Nasurdin, A.M. (2005). Turnover intentions of Malaysian Hotel Employees: The role of Human Resource Management Practices and Trust in Organization, Asean Journal of Hospitality and Tourism, 4(2): 115-127.

Igbal, A. (2010). An Empirical Assessment of Demographic Factors, Organisational Ranks and Organisational Commitment, International Journal of Business and Management, 5:16-27.

İmamoğlu, T. (2005). Veri madenciliğinde Karar Ağaçları ile Bir Öğrenci Ders Başarısı Tahmin Aracı, Yüksek Lisans Tezi, Kocaeli Üniversitesi Fen Bilimleri Enstitüsü, Kocaeli.

Jamal, M. (2011). Job Stress, Job Performance, and Organisational Commitment in a Multinational Company. An Empirical Study in Two Countries, International Journal of Business and Social Sciences, 2:20-29.

John, M.C. \& Taylor, W.T. (1999). Leadership Style, School Slimate and the Institutional Commitment of Teachers, International Forum, 2(1): 25-57.

Judge T.A. \& Locke, R.J. (1993). Effect of Dysfunctional Thought Processes on Subjective Well Being and Job Satisfaction, Journal of Applied Psychology, 78(3): 475-490.

Judge, T.A. \& Watanabe, S. (1993). Another Look at the Job Satisfaction-Life Satisfaction Relationship, Journal of Applied Psychology, 6: 939-948.

Kalaycı, S. (2006). SPSS Uygulamalı Çok Değişkenli İstatistik Teknikleri, Asil Yayın Dağıtım A.Ş. (2. Basım), Ankara.

Karsh, B., Booske, B.C. \& Sainfort, F. (2005). Job and Organizational Determinants of Nursing Home Employee Commitment, Job Satisfaction and Intent to Turnover, Ergonomics 48(10): 1260-1281.

Kayri, M. \& Boysan, M. (2007). Araştırmalarda Chaid Analizinin Kullanımı ve Baş Etme Stratejileri İle İlgili Bir Uygulama, Ankara Üniversitesi Eğitim Bilimleri Fakültesi Dergisi, 40(2):133-149

Koyuncugil, A.S. (2007). Borsa Şirketlerinin Sektörel Risk Profillerinin Veri Madenciliğiyle Belirlenmesi, Sermaye Piyasası Kurulu Araştırma Raporu, Araştırma Dairesi, Ankara.

Koyuncugil, A.S. \& Özgülbaş, N. (2008). İMKB’DE İşlem Gören Kobi’lerin Güçlü Ve Zayıf Yönleri: CHAID Karar Ağacı Uygulaması, Dokuz Eylül Üniversitesi İktisadi ve İdari Bilimler Fakültesi Dergisi, 23(1):1-21.

Kök, S.B. (2006). İş Tatmini Ve Örgütsel Bağlılığın İncelenmesine Yönelik Bir Araştırma, Atatürk Üniversitesi İktisadi ve İdari Bilimler Dergisi, 20(1): 291-310.

Kuria, S., Alice, O., \& Wanderi, P. (2012). Assessment of causes of Labour Turnover in Three and five Star-Rated Hotel in Kenya, International Journal of Bussiness and Social Science, 3(15), 311-317.

Kurşunoğlu, A., Bakay, E. \& Tanrıöğen, A. (2010). İlköğretim Okulu Öğretmenlerinin Örgütsel Bağlılık Düzeyleri, Pamukkale Üniversitesi Eğitim Fakültesi Dergisi, 28 : 101-115. 
Lam, S.S.K. (1995). Quality Management and Job Satisfaction, International Journal of Quality \& Reliability Management, 12 (4): 72-78.

Lam, T., Zhang, H. \& Baum, T. (2001). An investigation of Employees' Job Satisfaction: The Case of Hotels in Hong Kong, Tourism Management, 22: 157165.

Lashley, C. \& Lee-Ross, D. (2003). Organization Behavior for Leisure Services, Elsevier/Butterworth-Heinemann, Oxford.

Luqman, O.O., Bolaji, S. \& Abubakar, M.J. (2012). Job Satisfaction and Job Commitment: A Study of Quantity Surveyors in Nigerian Public Service, International Journal of Business and Management, 7(5): 179-192.

Luthans, B. Baack, D. \& Taylor, L. (1987). Organizational Commitment: Analysis of Antecedents, Human Relations, 40(4): 219-236.

Mamman, A., Kamoche, K. \& Bakuwa, R. (2011). Diversity, Organisational Commitment and Organisational Citizenship Behavior: An Organising Framework, Human Resource Management Review, 22: 285-302.

Mathieu, J.E. \& Zajac, D.M. (1990) A Review and Meta-Analysis of the Antecedent, Correlates, and Consequences of Oganisational Commitment, Psychological Bulletin, 108:171-194.

Matzler, K. \& Renzl, B. (2007). Personality Traits, Employee Satisfaction and Affective Commitment, Total Quality Management \& Business Excellence, 18(5): 589-598.

Meyer, J.P., Stanley, D.J., Herscovitch, L. \& Topolnytsky, L. (2002). Affective, Continuance, and Normative ve Commitment to the Organization: A Metaanalysis of Antecedents, Correlates, and Consequences, Journal of Vocational Behavior, 61: 20-52.

Meyer, J.P. \& Allen, N.J. (1997). Commitment in the Workplace: Theory, Research, and Application. Sage Publications: USA.

Meyer, J.P. \& Allen, N.J. (1991). A Three-Component Conceptualization Of Organizational Commitment, Human Resource Management Review, 1: 61-89.

Meyer, J.P. \& Herscovitch, L. (2001). Commitment in the Workplace: Toward a General Model, Human Resource Management Review, 11:299-326.

Meyer, J.P., Allen, N.J. \& Topolnysky, L. (1998). Commitment in a Changing World of Work, Canadian Psychology, 39:83-93.

Mohammed F. \& Eleswed, M. (2013). Job Satisfaction and Organizational Commitment: A Correlational Study in Bahrain, International Journal of Business, Humanities and Technology, 3(5):43-53.

Mowday, R.T., Porter, L.W. \& Steers, R.M., (1982). Employee- Organization Linkages, The Psychology of Commitment, Absenteeism and Turnover, New York, Academic Press.

Namasivayam, K. \& Zhao, X. (2007). An Investigation of the Moderating Effects of Organizational Commitment on the Relationships Between Work-Family Conflict and Job Satisfaction Among Hospitality in Indi, Tourism Management, 28: 12121223.

Nunnally, J.C. (1978). Psychometric Testing. New York: McGraw-Hill. 
Obeng, K. \& Ugboro, I. (2003). Organizational Commitment among Public Transit Employees: An Assessment Study, Journal of the Transportation Research Forum, 57(2): 83-98.

Organ, D.W. \& Ryan, K. (1995). A Meta-Analytic Review of Attitudinal and Dispositional Predictors of Organizational Citizenship Behavior, Personnel Psychology, 48:775-802.

Oshagbemi, T. (2000). Satisfaction with Co-Workers' Behaviour, Employee Relations, 22 (1): 88-106.

Oyewobi, L.O., Suleiman, B. \& Muhammad-Jamil, A. (2012). Job Satisfaction and Job Commitment: A Study of Quantity Surveyors in Nigerian Public Service, International Journal of Business and Management, 7(5): 179-192.

Özdevecioğlu, M. (2003). Algılanan Örgütsel Destek İle Örgütsel Bağlılık Arasındaki İlişkilerin Belirlenmesine Yönelik Bir Araştırma, Dokuz Eylül Üniversitesi İktisadi ve İdari Bilimler Fakültesi Dergisi, 18(2): 113-130.

Pelit, E. \& Güçer, E. (2006). Turizm Alanında Öğretmenlik Eğitimi Alan Öğrencilerin Turizm İşletmelerinde Yaptıkları Stajları Değerlendirmeleri Üzerine Bir Araştırma. Ticaret ve Turizm Eğitim Fakültesi Dergisi, 1:139-168.

Pelit, E. \& Öztürk, Y. (2010). Otel İşletmeleri İşgörenlerinin İş Doyum Düzeyleri: Sayfiye ve Şehir Otel İşletmeleri İşgörenleri Üzerinde Bir Araştirma. İşletme Araştırmaları Dergisi, 2(1): 43-72

Pourghaz, A., Tamini, K.B. \& Karamad, A. (2011). Do Demographic Characteristics Make a Difference to Job Satisfaction, Organizational Commitment and Burnout among Travel Agency Drivers? (A Case Study in Iran), Journal of Basic and Applied Scientific Research, 1:916-923.

Rue, L.W. \& Byars, L.L. (2005). Management: Skills and Application (Eleventh Edition). New York: New

Salami, S.O. (2008) Demographic \& Psychological Factors Predicting Organisational Commitment among Industrial Workers, Anthropologist, 10:31-38.

Saraçlı, S., Doğan, İ., Kaygısız, Z. \& Kaya, M. (2006). Osmangazi Üniversitesi İ.İ.B.F. Öğrencilerinin Bölüm Değiştirmeyi İsteyip İstemediklerinin İncelenmesi, Eğitim Araştırmaları Dergisi, 22:179-187.

Sarwar S. \& Abugre, J. (2013). The Influence of Rewards and Job Satisfaction on Employees in the Service Industry, The Business and Management Review, 3(2): 22-32.

Scott, A., Gavelle, H., Simoens, S., Bojke, C. \& Sibbald, B. (2006). Job Satisfaction and Quitting Intentions: A Structural Model of British General Practitioners, British Journal of Industrial Relations, 44 (3): 519-540.

Sevimli, F. \& İşcan, Ö.F. (2005). Bireysel Ve İş Ortamına Ait Etkenler Açısından İş Doyumu, Ege Akademik Bakış Dergisi, 5(1): 55-65.

Shields, M. \& Price, S. (2002). Racial Harassment, Job Satisfaction and Intentions to Quit: Evidence from British Nursing Profession, Economica, 69: 295-362.

Sığrı, Ü. (2007). İş Görenlerin Örgütsel Bağl1lıklarının Meyer Ve Allen Tipolojisiyle Analizi: Kamu Ve Özel Sektörde Karşılaştırmalı Bir Araştırma, Anadolu Üniversitesi Sosyal Bilimler Dergisi, 7(2): 261-268. 
Silva, P. (2006). Effects of Disposition on Hospitality Employee Job Satisfaction and Commitment, International Journal of Contemporary Hospitality Management, 18(4): 317-328.

Smith, T. (2007). Job Satisfaction in America: Trends and Socio-Demographic Correlates. Chicago: NORC.

SPSS (2001). Answer Tree 3.0 User's Guide, USA: SPSS Inc

Sousa-Poza A \& Sousa-Poza A.A. (2000). Well-being at Work. A cross-national Analysis of the Levels and Determinants of job Satisfaction, Journal of SocioEconomics, 29(6): 517-538.

Suma, S. \& Lesha J. (2013). Job Satisfaction And Organizational Commitment: The Case Of Shkodra Municipality, European Scientific Journal, 9(17):41-51.

Şengül, C.M. (2008). Örgüt Çalışanlarının Kişilik, İş Tatmini Ve Örgütsel Bağlılıkları Arasındaki İlişskinin İncelenmesi, Doktora Tezi, Celal Bayar Üniversitesi Sosyal Bilimler Enstitüsü, Manisa.

Tarigan, V. \& Ariani, D.W. (2015). Empirical Study RelationsnJob Satisfaction, Organizational Commitment, and Turnover Intention, Advances in Management \& Applied Economics, 5(2):21-42

Taşkın, F. \& Dilek, R. (2010). Örgütsel Güven Ve Örgütsel Bağlılık Üzerine Bir Alan Araştırması, Organizasyon Ve Yönetim Bilimleri Dergisi, 2(1): 37-46.

Testa, M.R. (2001). Organizational Commitment, Job Satisfaction, and Effort in the Service Environment, The Journal of Psychology, 135(2): 226-236.

Tett, R.P. \& Meyer, J.P. (1993). Job Satisfaction, Organizational Commitment, Turnover Intention, And Turnover: Path Analysis Based On Meta-Analytic Findings, Personnel Psychology, 46: 259-293.

Toker, B. (2007). Demografik Değişkenlerin İş Tatminine Etkileri: İzmir'deki Beş Ve Dört Yıldızlı Otellere Yönelik Bir Uygulama, Doğuş Üniversitesi Dergisi, 8(1):92-107.

Tracey, B. \& Hinkin, T. (2008). Contextual Factors and Cost Profiles Associated with Employee Turnover, Cornell Hospitality Quarterly, 49(1):12-27.

Tutar, H. (2007). Erzurum'da Devlet Ve Özel Hastanelerde Çalışan Sağlık Personelinin İşlem Adaleti,Işs Tatmini Ve Duygusal Bağl1lık Durumlarının İncelenmesi, Süleyman Demirel Üniversitesi İktisadi ve İdari Bilimler Fakültesi, 12(3): 97-120

Türe, M., Tokatlı, F. \& Kurt, Ü. (2009). Using Kaplan-Meirer Analysis Together With Decision Tree Methods (C\&RT, CHAID, QUEST, C4.5 and ID3) In Determining Recurrence-Free Survival of Breast Cancer Patients, Expert Systems With Applications, 36(2): 2017-2026

Tütüncü, Ö. (2000). Karayolu Ulaştırma İşletmelerinde İşten Ayrılma Eğiliminin Analizi, Dokuz Eylül Üniversitesi Sosyal Bilimler Enstitüsü Dergisi 2(4):106-120.

Üngüren, E. \& Doğan H. (2010). An Evaluation of Job Satisfaction with CHAID Analysis: A Research in Five-Stars Hotels, Cumhuriyet University, Journal of Economics and Administrative Sciences, 11(2):39-52.

Vandenberghe, C. \& Tremblay, M. (2008). The Role of Pay Satisfaction and Organizational Commitment in Turnover Intentions: A Two-Sample Study, Journal of Business and Psychology, 22(3): 275-286 
Wasti, S.A. (2000). Meyer ve Allen'in üç Boyutlu Örgütsel Bağll1ık Ölçeğinin Geçerlilik Ve Güvenilirlik Analizi, 8. Ulusal Yönetim ve Organizasyon Kongresi Bildiriler Kitabı, Nevşehir, 25-27 Mayıs, 401-410.

Wasti, S.A. (2002). Affective and Continuance Commitment to the Organization: Test of An Integrated Model in the Turkish Context, International Journal of Intercultural Relations, 26: 525-550

Weiss, H.M. (2002). Deconstructing Job Satisfaction Seperating Evaluations, Beliefs and Affective Experiences, Human Resource Management Review, 12:173-194.

Westover, J.H. \& Taylor, J. (2010). International Differences in Job satisfaction: The Effects of Public Service Motivation, Rewards and Work Relations, International Journal of Productivity and Performance Management,59(8): 811-828.

Woods, R.H. (1997). Human Resources Management, The Educational Institute of the American Hotel \& Motel Association, Michigan.

Yalçın, A. \& İplik F.N. (2005). Beş Yıldızlı Otellerde Çalışanların Demografik Özellikleri İle Örgütsel Bağllıkları Arasındaki İlişkiyi Belirlemeye Yönelik Bir Araştırma: Adana İli Örneği, Çukurova Üniversitesi Sosyal Bilimler Enstitüsü Dergisi, 4(1): 395-412.

Yavuz, E. (2009). İşgörenlerin Dönüşümcü Liderlik ve Örgütsel Bağll1ık İle İlgili Tutumlarına Yönelik Bir Araştırma, İşletme Araştırmaları Dergisi, 1(2): 51-69.

Yousef, D.A. (2002). Job satisfaction as a Mediator of the Relationship Between Role Stressors and Organizational Commitment: A study from an Arabic Cultural Perspective, Journal of Managerial Psychology, 17(4): 250-266.

Yousef, D.A. (1998). Satisfaction with Job Security as a Predictor of Organizational Commitment and Job Performance in a Multicultural Environment, International Journal of Manpower,19(3): 184-194.

Yüceler, A. (2009). Örgütsel Bağlllık ve Örgüt İklimi İlişkisi: Teorik ve Uygulamalı Bir Çalışma, Selçuk Üniversitesi Sosyal Bilimler Enstitüsü Dergisi, 22: 445-458. 